\title{
The performance of stability test using Bantak aggregate and AC50/70 as polymer on Marshall characteristic
}

\author{
Tino Putro Pangestu ${ }^{1 *}$, Wasiu Akande Ahmad², Adi Setiabudi Bawono ${ }^{3}$, Mohamad Aqif ${ }^{4}$ \\ ${ }^{1}$ PT. PLN (Persero) UIP Maluku, UPP Kitring Maluku Utara, J1. Wijaya Kusuma, Kota Baru, Ternate Tengah, Maluku Utara, 97751, \\ Indonesia \\ ${ }^{2}$ African Regional Centre for Space Science and Technology Education, English, IIe-Ife, 220282, Nigeria \\ ${ }^{3}$ Faculty of Civil Engineering Technology, Universiti Malaysia Pahang, Gambang, 26300 Malaysia \\ ${ }^{4}$ Undergraduate Student, Department of Civil Engineering, Faculty of Engineering, Universitas Negeri Yogyakarta, 55281, Indonesia \\ E-mail: ${ }^{1}$ tinoputropangestu@gmail.com*; ${ }^{2}$ wasto2007@gmail.com ; ${ }^{3}$ adi.setiabudi@uty.ac.id; ${ }^{4}$ elhaji.akiv@gmail.com. \\ * corresponding author
}

ABSTRACT

ARTICLE INFO

This study aims to determine Marshall's characteristics using asphalt binder modified polymer AC 50/70 (Starbit E-55) using local Bantak material. The test method used is a hot mix asphalt (Hot Mix) with the Marshall method. The asphalt content used was $5 \%$ successively; $5.5 \% ; 6 \% ; 6.5 \%$; and $7 \%$ consisting of 3 specimens for each variant. The research was carried out at the Material Laboratory of the Department of Civil Engineering and Planning, Faculty of Engineering, Yogyakarta State University. The results of the Marshall characteristic performance test at the Optimum Asphalt Level (KAO) $6.5 \%$ are as follows: Marshall stability mean value is $1197.6 \mathrm{~kg}$, Density mean value is $2.34 \mathrm{gr} / \mathrm{cc}$, the mean value of melt (Flow) is $3,1 \mathrm{~mm}$, the mean value of VIM (Void in Mix) was $4.83 \%$, the mean value of VMA (Void in Mineral Aggregate) was $13.40 \%$, the mean value of VFB (Void Filled Bitumen) was $60.61 \%$, and the mean value of MQ (Marshall Quotient) $391.08 \mathrm{~kg} / \mathrm{mm}$.

This is an open-access article under the CC-BY-SA license
Article history

Received:

3 March 2021

Revised:

9 March 2021

Accepted:

9 March 2021

Keywords

Bantak

Characteristic

Polymer

\section{Introduction}

Indonesia has abundant natural resources, which are marked by active volcanoes in some of its areas. One of the active volcanoes located in Indonesia, especially in Yogyakarta, is Mount Merapi. In Yogyakarta, Merapi, almost every two or five years, releases its hot lava [1], [2]. Merapi always releases hot lava and materials (rock, sand, and volcanic ash) when an eruption occurs. From the materials of Mount Merapi, such as rock and sand, many people can use it. However, we need to know that there are materials from Merapi underutilized by the community, such as Bantak (mining residue at the bottom of the Sabo DAM). 
Journal of Engineering and Applied Technology

Vol. 1, No. 2, August 2020, pp. 97-109

Bantak stone is the name of the community around Mount Merapi. The bantak stone is called coarse aggregate, while the coarse aggregate is a rock that is classified as andesite rock. Andesite rocks are a group of igneous rocks formed from lava that comes out of the earth's bowels and freezes on the surface of the earth [3]. The availability of Bantak aggregate is abundant, but its use is very minimal. Meanwhile, according to [4-8] the Bantak aggregate has passed the examination [9].

Furthermore, Indonesia has several volcanoes that are still active and can produce much material. Indonesia is also a country that is arguably rich in petroleum. So that Indonesia can produce refined petroleum products, for example, such as asphalt. Asphalt is a black or dark brown material that at room temperature is solid to slightly solid. If heated to a specific temperature, it becomes soft/liquid. According to [10], Asphalt is a continuous process from the residue of petroleum distillation.

Asphalt can be expanded or modified with polymers and produce polymer modified bitumen. Polymer-modified asphalt is asphalt that is deliberately made with additives in which there are monomer molecules. Monomer molecules are polymer molecules that have been crushed using a colloid mill machine so that the molecules are shaped like hairs with micron sizes.

The concept of modifying asphalt into polymer modified asphalt, namely on static loads, instantaneous elastic (the elastic properties of asphalt that immediately works when given a static load) can be distinguished from delayed elastic (elastic properties of asphalt that do not work immediately when given a static load) while at dynamic loads indistinguishable, fixed deformation is caused by the viscous properties of the material, according to the visco-elastic properties of asphalt, the deformation will increase at high temperatures and low vehicle speeds.

This modified asphalt with polymer aims to increase resistance to deformation at high temperatures and resistance to fatigue cracking at low temperatures and load repetitions. The method used to modify the asphalt is by increasing the stiffness modulus of high-temperature asphalt and reducing the stiffness modulus of asphalt at low temperatures without changing many properties at other temperatures. This modified asphalt has a positive impact, namely an increase in the stiffness modulus of the asphalt, this will increase the dynamic stiffness of the asphalt and also increase the elastic component of the asphalt, this can increase flexibility.

Based on the concept of the modification of polymer asphalt and the use of Bantak aggregate, the strength of this modified asphalt tends to be stronger than that of ordinary AC asphalt, because the asphalt in its manufacture has added additives. Although [4] has investigated the use of polypropylene fiber additives, the quality of the polymer modification in question is slightly different from the characteristics of other additives. Meanwhile, the characteristic value of polymer asphalt with Bantak aggregate mixture has not been known, including the amount of optimum asphalt content (KAO) used. The Bantak aggregate was chosen because it has not been widely used in the field of civil engineering, especially for flexible pavement.

\section{Method}

This study used a laboratory experimental method consisting of independent, dependent, and control variables. The relationship between variables is shown in Fig. 1 and the research flowchart is presented in Fig. 2. 
Journal of Engineering and Applied Technology

Vol. 1, No. 2, August 2020, pp. 97-109

\section{Materials}

The materials used in this study include (1) Bantak aggregate; (2) filler (Bantak); (3) Bituminous materials (polymer AC 50/70).

\section{Results and Discussion}

\subsection{Bituminous inspection}

The materials used for the mixture of asphalt concrete in this study consisted of 50/70 penetration polymer modified asphalt, Bantak coarse aggregate, Bantak fine aggregate, and filler from Bantak rock ash [11] [12]. 50/70 penetration is lower than 60/70 penetration bitumen. The difference from the penetration of the pen polymer modified asphalt. 50/70 and pen. $60 / 70$ [13], namely $67.86 \mathrm{~mm}$ and $69.07 \mathrm{~mm}$, respectively. The softening point of polymer modified bitumen, 50/70 penetration, is higher than that of $60 / 70$ penetration bitumen. The amount of softening point, flash point, and burning point of asphalt [14] and specific gravity [15] presented in Table 1 and Table 2.

Table 1. Inspection results of 50/70 penetration polymer modification asphalt

\begin{tabular}{ccccc}
\hline No & Test method & Specification & Results & unit \\
\hline 1 & Penetration $25^{\circ}$ & $50-70$ & 67,86 & $0.1 \mathrm{~mm}$ \\
2 & Softening point & $55-60$ & 55.30 & ${ }^{\circ} \mathrm{C}$ \\
3 & Flashpoint & 250 & 283 & ${ }^{\circ} \mathrm{C}$ \\
4 & Flashpoint (burn) & - & 286,7 & ${ }^{\circ} \mathrm{C}$ \\
5 & Specific gravity & $\geq 1$ & 1.052 & $\mathrm{gr} / \mathrm{cc}$ \\
\hline
\end{tabular}

\section{Independent variables:}
a. bituminous $(5 \%)$
b. bituminous $(5,5 \%)$
c. bituminous $(6 \%)$
d. bituminous $(6,5 \%)$
e. bituminous $(7 \%)$
2. Dependent Variables:
a. Specific gravity
b. Stability
c. Flow
d. VFB
e. VIM
f. VMA
g. Marshall Quotient (MQ)
h. Density

\section{Control variables \\ a. Aggregate \\ b. Type of bituminous material \\ c. $\%$ bituminous in a mix \\ d. Mixing method \\ e. Immersion of specimen \\ f. Immersion temperature \\ g. Testing method}

Fig. 1. Relationship between variables 
Journal of Engineering and Applied Technology

Vol. 1, No. 2, August 2020, pp. 97-109

Table 2. Inspection results of $60 / 70$ penetration asphalt

\begin{tabular}{ccccc}
\hline No & Test method & Specification & results & Unit \\
\hline 1 & Penetration $25^{\circ}$ & $60-79$ & 69,07 & $0.1 \mathrm{~mm}$ \\
2 & Softening point & $48-58$ & 54,10 & ${ }^{\circ} \mathrm{C}$ \\
3 & Flashpoint & $>200$ & 322,67 & ${ }^{\circ} \mathrm{C}$ \\
4 & Flashpoint (burn) & - & 324,67 & ${ }^{\circ} \mathrm{C}$ \\
5 & Specific gravity & $\geq 1$ & 1.037 & $\mathrm{gr} / \mathrm{cc}$ \\
\hline
\end{tabular}

\subsection{Stability test}

Based on the test results show that all asphalt concrete mixtures meet the requirements of the Marshall compressive test. The stability test is presented in Table 3 and Fig. 3. The test results show that at the same review of asphalt content, the stability value of the asphalt concrete mixture is greater in the range of asphalt content of 5\% $-6.5 \%$ and at $7 \%$ asphalt content has decreased the value of stability. Fig. 3 shows that the regression equation is shown in the form of a line, reflecting that the asphalt concrete mixture has the highest stability at asphalt content of $6.5 \%$ with a stability value of $1197.76 \mathrm{~kg}$.

The stability value obtained in the test results is still above the minimum stability value requirement for the required heavy traffic [15], which is $800 \mathrm{~kg}$. The stability value of the asphalt concrete mixture using AC 50/70 asphalt modified asphalt with a content of $6.5 \%$ has a greater stability value, namely $1197.76 \mathrm{~kg}$, compared to the stability value in hot asphalt mixtures using AC 60/70 asphalt with a grade of $6.5 \%$ was $1087.1 \mathrm{~kg}$. These results indicate that polymer modified asphalt has better resistance to load repetition compared to ordinary AC asphalt. The results of this test are also supported by research data [4] which modified the polypropylene fiber material in a hot asphalt mixture, which has better resistance than ordinary mixtures.

\subsection{Flow}

Flow or melt shows the amount of decrease or deformation that occurs in the hard layer due to bearing the load it receives. The decrease or deformation that occurs is closely related to other Marshall characteristic values, such as VFB (Void Filled Bitumen), VIM (Void In Mix), and their stability. The flow value is influenced, among others, by the aggregate gradation, asphalt content, and the compaction process which includes compaction temperature and compaction energy.

Table 3. Stability test

\begin{tabular}{ccc}
\hline Specimens & $\begin{array}{c}\text { Bituminous } \\
(\boldsymbol{\%})\end{array}$ & $\begin{array}{c}\text { Stability averages } \\
(\mathbf{k g})\end{array}$ \\
\hline $\mathrm{S}_{5}$ & 5 & 1014.54 \\
$\mathrm{~S}_{5.5}$ & 5.5 & 1072.92 \\
$\mathrm{~S}_{6}$ & 6 & 1168.64 \\
$\mathrm{~S}_{6.5}$ & 6.5 & 1197.76 \\
$\mathrm{~S}_{7}$ & 7 & 1117.74 \\
\hline
\end{tabular}

Notes: each specimen consist of three samples 
Journal of Engineering and Applied Technology

Vol. 1, No. 2, August 2020, pp. 97-109

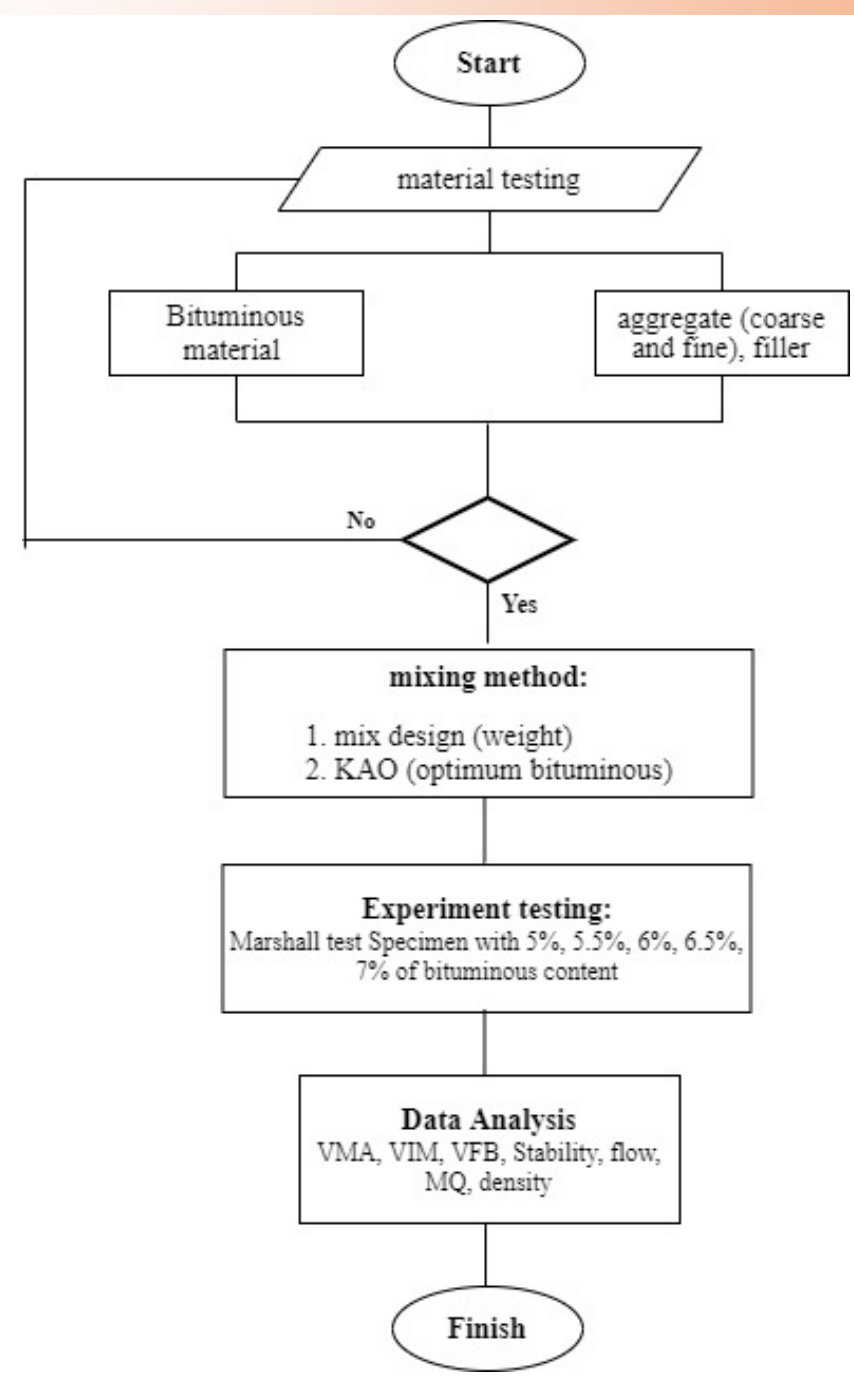

Fig. 2. Research flowchart

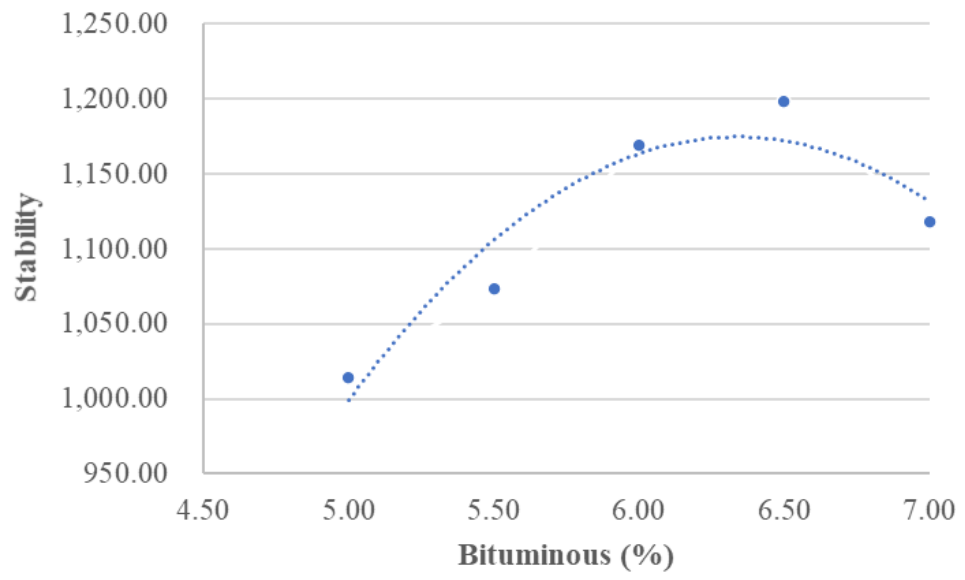

Fig. 3. Stability versus Bituminous (\%) 
Journal of Engineering and Applied Technology

Vol. 1, No. 2, August 2020, pp. 97-109

Mixtures that have a low flow value and high stability tend to be stiff and brittle, while mixtures that have a high flow value with low stability tend to be plastic and can easily change shape when subject to traffic loads. Asphalt consists of two main components, namely asphaltenes and malteness. Asphaltenes give brown or black color to the asphalt, while malteness and oil will also affect the flow value. The results of the Marshall flow test are presented in full in Table 4 and Fig. 4.

Table 4. Flow test

\begin{tabular}{ccc}
\hline Specimens & $\begin{array}{c}\text { Bituminous } \\
(\%)\end{array}$ & $\begin{array}{c}\text { Flow average } \\
(\mathbf{m m})\end{array}$ \\
\hline $\mathrm{S}_{5}$ & 5 & 3.4 \\
$\mathrm{~S}_{5.5}$ & 5.5 & 2.6 \\
$\mathrm{~S}_{6}$ & 6 & 2.5 \\
$\mathrm{~S}_{6.5}$ & 6.5 & 3.1 \\
$\mathrm{~S}_{7}$ & 7 & 3.2 \\
\hline
\end{tabular}

Notes: each specimen consist of three samples

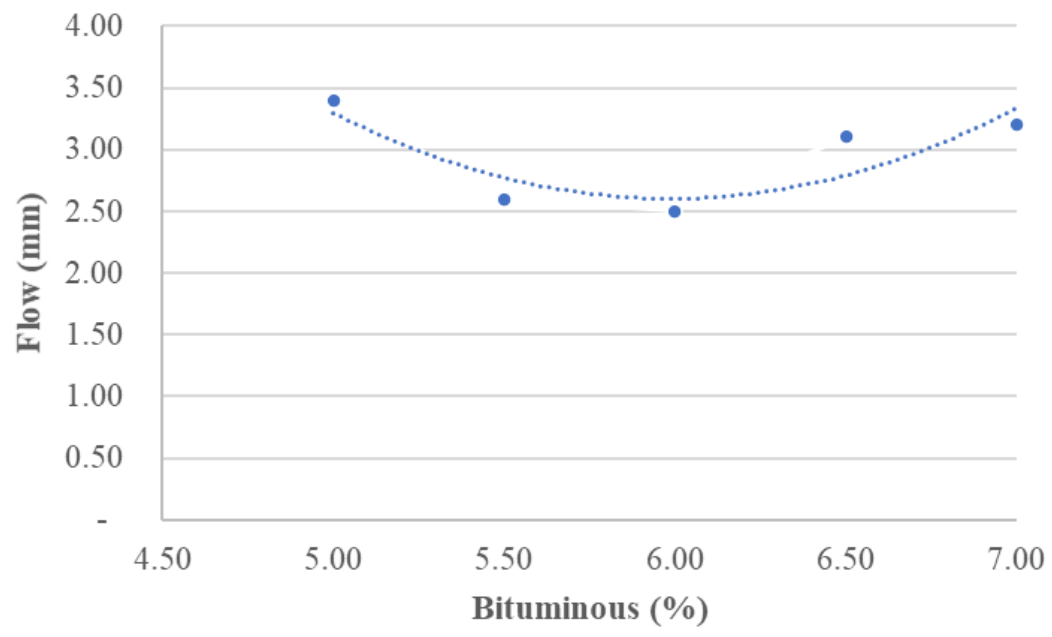

Fig. 4. Flow versus bituminous (\%)

Figure 4 above the test results show that in a different view of asphalt content, the flow value in the asphalt concrete mixture from 5\% to 5.5\% levels has decreased to 6\% levels. After that, at a level of $6 \%$ to $7 \%$, it has increased. Fig. 4 above shows that the equation is shown in the form of a polynomial line, reflecting that the asphalt concrete mixture has the lowest flow at $6 \%$ asphalt content with a flow value of $2.5 \mathrm{~mm}$.

\subsection{Voids filled bitumen}

VFB (Void Filled Bitumen), states the process of an air cavity filled with asphalt in a mixture that has undergone compaction. This VFB value is the water and air impermeability, as well as the elastic properties of the mixture. The VFB value is influenced by several factors such as energy, compaction temperature, type and content of asphalt, as well as the gradation of the aggregate. The greater the VFB value means that the more air cavities are filled with asphalt so the water and air 
Journal of Engineering and Applied Technology

Vol. 1, No. 2, August 2020, pp. 97-109

resistance of the mixture will be higher. VFB values that are too high will cause the pavement layer to bleed easily or increase the asphalt surface. The VFB (Void Filled Bitumen) value that is too small will cause the impermeable mixture to reduce water because a little cavity is filled with asphalt. With many empty voids, water and air will easily enter the hard layer so that the durability of the hard layer will be reduced. The complete VFB calculation results are presented in Table 5 and Fig. 5.

Table 5. VFB test

\begin{tabular}{ccc}
\hline Specimens & $\begin{array}{c}\text { Bituminous } \\
(\%)\end{array}$ & VFB \\
\hline $\mathrm{S}_{5}$ & 5 & 7.04 \\
$\mathrm{~S}_{5.5}$ & 5.5 & 21.96 \\
$\mathrm{~S}_{6}$ & 6 & 38.42 \\
$\mathrm{~S}_{6.5}$ & 6.5 & 60.61 \\
$\mathrm{~S}_{7}$ & 7 & 59.08 \\
\hline
\end{tabular}

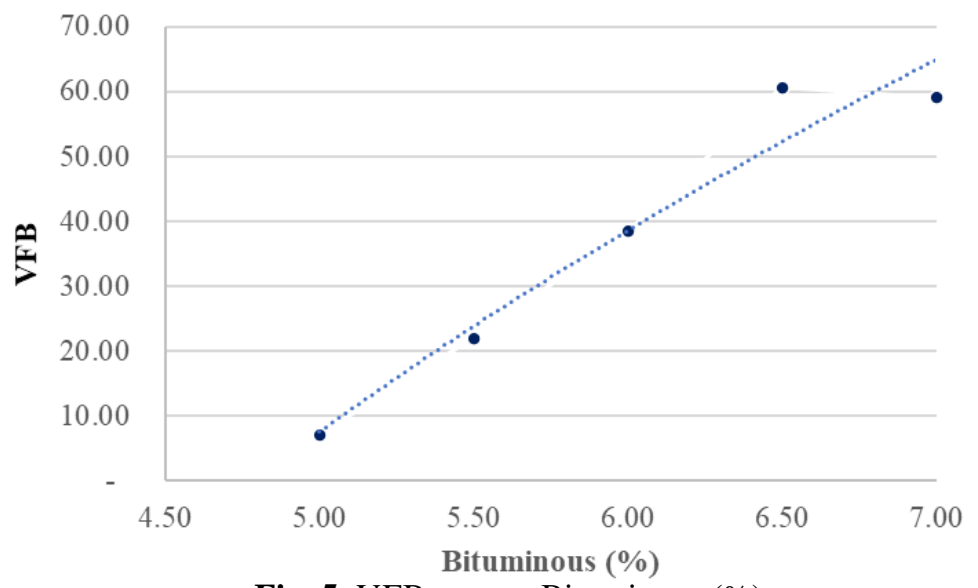

Fig. 5. VFB versus Bituminous (\%)

Figure 5 the VFB (Void Filled Bitumen) value is obtained at 5\% asphalt content; 5.5\%; 6\%; and $7 \%$ did not meet the requirements, namely because the VFB value was below $60 \%$ and did not comply with the requirements of [9]. While the asphalt content of $6.5 \%$ meets the requirements, namely with a VFB value of $60.61 \%$.

\subsection{Voids In Mix (VIM)}

VIM (Void In Mix) is the number of cavities in the mixture expressed as a percentage. The air cavity contained in the mixture is needed to provide space for the mixed elements according to their elastic properties. Therefore, the VIM value will determine the characteristics of the mixture. VIM (Void In Mix) value is influenced by aggregate gradation, asphalt content, and density.

If the VIM (Void In Mix) value is too high, the durability of the hard layer will be reduced because the cavity is too large, which will make it easier for water and air to enter the pavement layer. The air will oxidize the asphalt so that the asphalt blanket becomes thin and the cohesion of the asphalt is reduced. If this happens, it will cause raveling, while the water will dissolve the unoxidized part of the asphalt so that the reduction in the amount of asphalt will be faster. 
Journal of Engineering and Applied Technology

Vol. 1, No. 2, August 2020, pp. 97-109

A VIM value that is too low will cause bleading of the hard layer easily. In addition to bleading, with a low VIM stiffness, the hard layer will experience cracking when it receives traffic loads because it is not flexible enough to accept the deformation that occurs. The complete VIM calculation results are presented in Table 6 and Fig. 6.

Table 6. VIM test

\begin{tabular}{ccc}
\hline Specimens & Bituminous (\%) & VIM \\
\hline $\mathrm{S}_{5}$ & 5 & 10.57 \\
$\mathrm{~S}_{5.5}$ & 5.5 & 8.43 \\
$\mathrm{~S}_{6}$ & 6 & 6.48 \\
$\mathrm{~S}_{6.5}$ & 6.5 & 4.83 \\
$\mathrm{~S}_{7}$ & 7 & 4.97 \\
\hline
\end{tabular}

Fig. 17 above shows that the VIM (Void In Mix) value that meets the requirements [9] of 3.5\% $-5.5 \%$ is for asphalt concrete mixture with asphalt content of $6.5 \%$ and $7 \%$, namely the VIM (Void In) value. Mix) of $4.83 \%$ and $4.97 \%$.

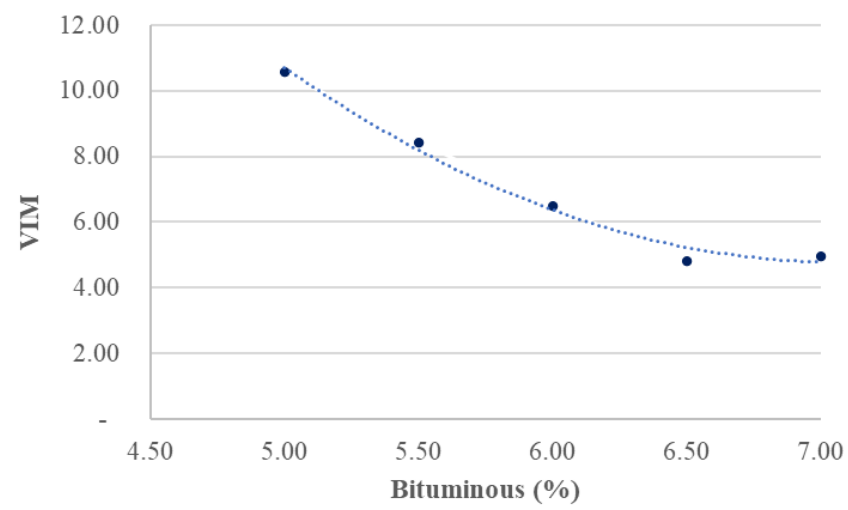

Fig. 6. Void in mixed versus bituminous (\%)

\subsection{VMA (Void in Mineral Aggregate)}

VMA (Void In Mineral Aggregate) is the air cavity that exists between the mineral aggregates in the hot asphalt mixture which has been compacted including the space filled with asphalt. VMA is expressed as a percentage of the hot asphalt mixture. VMA is used as a space to accommodate the asphalt and the volume of air cavities required in the hot asphalt mixture, the value of VMA is influenced by the asphalt content, the gradation of the stacking material, the number of collisions, and the temperature of compaction. The relationship between VMA and asphalt content can be seen in Table 7 and Fig. 7.

Table 7. VMA test

\begin{tabular}{ccc}
\hline Specimens & Bituminous (\%) & VMA \\
\hline $\mathrm{S}_{5}$ & 5 & 11.36 \\
$\mathrm{~S}_{5.5}$ & 5.5 & 10.80 \\
$\mathrm{~S}_{6}$ & 6 & 10.45 \\
$\mathrm{~S}_{6.5}$ & 6.5 & 13.40 \\
\hline
\end{tabular}


Journal of Engineering and Applied Technology

Vol. 1, No. 2, August 2020, pp. 97-109

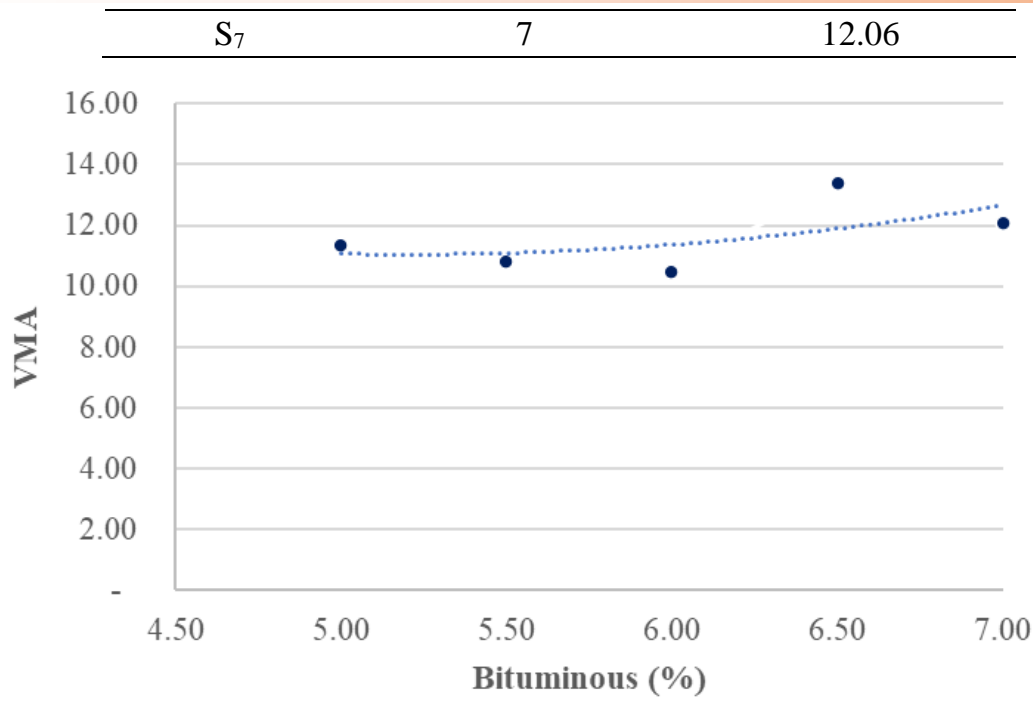

Fig. 7. VMA versus AC 50/70 polymer (\%)

Fig. 7 shows that the asphalt content of $6.5 \%$ and $7 \%$ in the asphalt concrete mixture meets the requirements of the Marshall stability test [9] which is greater than $13 \%$.

\subsection{Marshall Quotient (MQ)}

The Marshall Quotient (MQ) value is the quotient between stability and fatigue (flow) and is an approach to the level of stiffness and flexibility of the mixture. The greater the Marshall Quotient (MQ) value means that the mixture is stiffer and conversely the smaller the Marshall Quotient (MQ) is, the more flexible it will be. The complete calculation results (MQ) are presented in Table 8 and Fig. 8 .

Table 8. MQ test results

\begin{tabular}{ccc}
\hline Specimens & Bituminous (\%) & MQ \\
\hline $\mathrm{S}_{5}$ & 5 & 303.45 \\
$\mathrm{~S}_{5.5}$ & 5.5 & 416.82 \\
$\mathrm{~S}_{6}$ & 6 & 476.34 \\
$\mathrm{~S}_{6.5}$ & 6.5 & 391.08 \\
$\mathrm{~S}_{7}$ & 7 & 343.54 \\
\hline
\end{tabular}

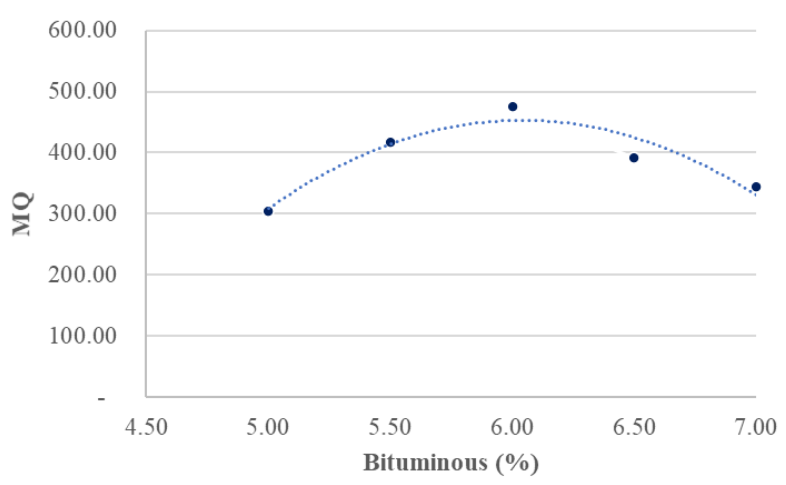


Journal of Engineering and Applied Technology

Vol. 1, No. 2, August 2020, pp. 97-109

Fig. 8. MQ versus AC 50/70 polymer (\%)

Fig. 8 shows that the asphalt concrete mixture with asphalt content is $5 \% ; 5.5 \% ; 6 \% ; 6.5 \%$; and 7\% had maximum MQ (Marshall Quotient) values, namely 303.45; 416.82; 476.34; 391.08; and $343.54 \mathrm{~kg} / \mathrm{mm}$. Overall asphalt concrete mixture using bantak aggregate meets the MQ requirements based on [9], which is above $250 \mathrm{~kg} / \mathrm{mm}$.

\subsection{Density}

Density is the density level of the mixture after it is compacted. Density is the weight of the mixture per unit volume. The factors that influence density are aggregate grading, bitumen content, aggregate density, quality of shrinkage, and compaction process which includes temperature and number of collisions. A mixture that has a density value will be able to withstand a greater load when compared to a mixture that has a low density. The full density test results are presented in Table 9 and Fig. 9.

Table 9. Density test

\begin{tabular}{ccc}
\hline Specimens & Bituminous (\%) & Density \\
\hline $\mathrm{S}_{5}$ & 5 & 2.28 \\
$\mathrm{~S}_{5.5}$ & 5.5 & 2.31 \\
$\mathrm{~S}_{6}$ & 6 & 2.33 \\
$\mathrm{~S}_{6.5}$ & 6.5 & 2.34 \\
$\mathrm{~S}_{7}$ & 7 & 2.31 \\
\hline
\end{tabular}

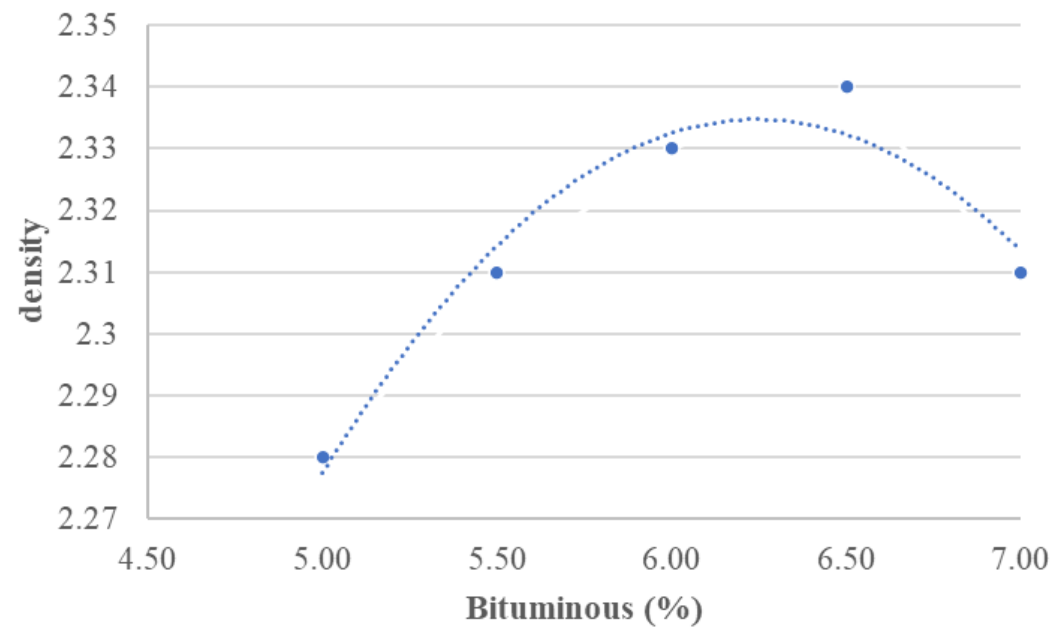

Fig. 9. Density versus AC 50/70 polymer (\%)

Figure 9 above shows a stable density for each asphalt concrete mixture. The above results indicate that all asphalt concrete mixtures meet the requirements of the Marshall compressive test because there are no special requirements for density values in determining the optimum asphalt content value [17]. 
Journal of Engineering and Applied Technology

Vol. 1, No. 2, August 2020, pp. 97-109

\subsection{Determination of the Optimum Asphalt Content}

The optimum asphalt content is the amount of asphalt used in the mixture to achieve the stability, flow, VMA, VIM, density, and Marshall Quotient requirements. Determination of the optimum asphalt content to determine the amount of effective asphalt content in the mixture required for the manufacture of new specimens with the same aggregate composition but with predetermined optimum asphalt content. Below is the determination of the optimum bitumen content from the asphalt mixture using Bantak aggregate and polymer modified asphalt.

In the asphalt concrete mixture using modified asphalt polymer AC 50/70 with bantak aggregate obtained at a value of $6.5 \%$ with a VIM value of $4.83 \%$; the VFB value is $60.61 \%$; the VMA value is $13.40 \%$; the stability value is $1197.76 \mathrm{~kg}$; the flow value is $3.1 \mathrm{~mm}$, and the value is MQ $391.08 \mathrm{~kg} /$ $\mathrm{mm}$.

\subsection{Comparison of the Quality of Natural Aggregates and Bantak Aggregates}

The test results show that the VIM and Stability values for the Bantak aggregate mixture have a greater value than the natural aggregate. This is influenced by the larger bantak aggregate cavity, causing the cavity to be filled with bituminous material. However, this value is inversely related to VFB and VMA, which have a smaller yield than VIM, the bitumen cavity cannot be completely absorbed due to the additive effect. The effect of additive materials also results in lower flow values and larger MQ values. This means that polymer modified asphalt has better durability than ordinary asphalt.

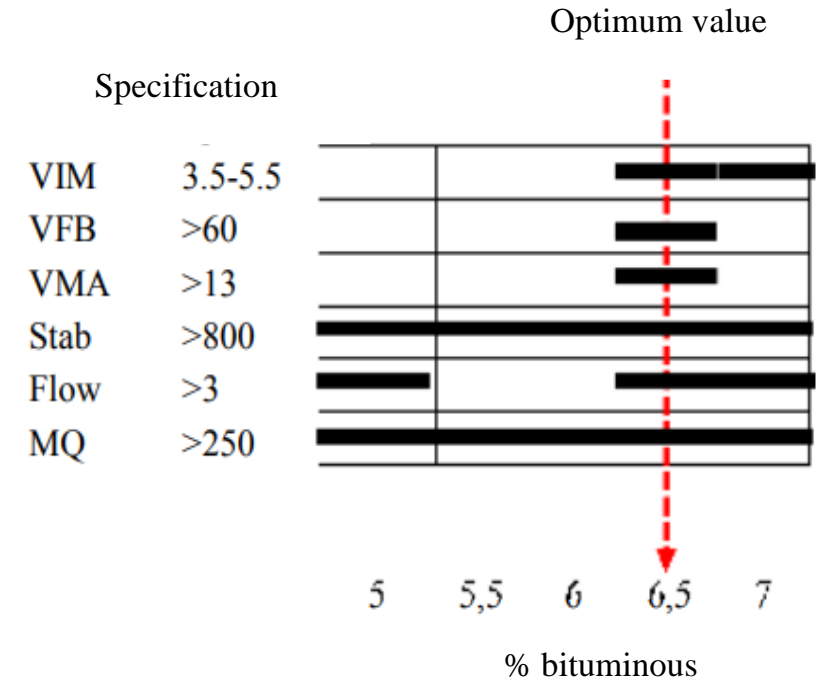

Fig. 10. The optimum value of AC 50/70 polymer (\%) on asphalt mixture

\section{Conclusion}

Based on the results of the above analysis, it can be concluded that the Marshall characteristic values in the use of polymer modified asphalt in terms of the Marshall test using the optimum bitumen content with VIM and VMA values are $4.83 \%$ and $13.40 \%$, respectively; VFB and stability values 
Journal of Engineering and Applied Technology

Vol. 1, No. 2, August 2020, pp. 97-109

were $60.61 \%$ and $1197.76 \mathrm{~kg}$, respectively; the values of flow, MQ, and density are $3.1 \mathrm{~mm}$ respectively; $391.08 \mathrm{~kg} / \mathrm{mm}$; and 2,342 $\mathrm{gr} / \mathrm{cm}^{3}$. Meanwhile, the value of the optimal asphalt content (KAO) asphalt modified AC 50/70 polymer which is used as a binder is $6 \%$.

\section{Acknowledgment}

The first author acknowledges, appreciates, and is grateful for the support of the Department of Civil Engineering for making this research a reality. The materials and supporting laboratory experiments were used to implement the works in this research.

\section{References}

[1] Widodo, D.R, Nugroho, S.P., and Asteria, D. "Analysis of Causes of Communities to Remain in Disaster-Prone Areas of Merapi (Study on the Slopes of Merapi, Cangkringan District, Sleman Regency, Yogyakarta Special Region)”. Jurnal Ilmu Lingkungan, vol. 15, pp.135-142, 2017, ISSN 1829-8907. (In Indonesian)

[2] Subandriyo. "Merapi Volcanoes Threats Post-Eruption 2010 Based on Modeling Results of Hot Clouds and Lava to Support Spatial / Regional Planning Based on Disaster Mitigation". Proceedings of the National Seminar on the Concept of Living in Harmony with Disaster Risk, Hotel Inna Garuda Yogyakarta, 25 Mei 2012, Yogyakarta. (In Indonesian)

[3] Sophian, R.I., Patonah, A., Febriwan, M. "Andesitic Rock Quality Based On Compressive Strength and Petrology Approach". Bulletin of Scientific Contribution, Vol. 9, pp.152-162, December 2011.

[4] Faqih, M., Pramudiyanto. "Performance Test of Bantak Merapi Aggregate Marshall Using Polypropylene Fibers". INERSIA, vol. 10, pp. 1-12, Mei 2014.

[5] Ke, Z., Yaofei, L., Yunze, W., Wenlong, L., Gan, Y. "Material optimization and optimum asphalt content design of asphalt mixture in salty and humid environment". Construction and Building Materials, vol. 196, pp. 703-713, January 2019.

[6] Zhenliang, J., Changbin, H., Said, E., Xiaoyan Z.A.O., AbdEl, H. "Identifying optimal polymer type of modified asphalt based on damping characteristics". Construction and Building Materials, vol. 173, pp. 308-316, June 2018.

[7] Y. J. Jiang, L. F. Fan. "An experimental investigation of optimal asphalt-aggregate ratio for different compaction methods". Construction and Building Materials, vol. 91, pp.111-115, August 2015.

[8] Ahmed, A., Zaman T.T., Humam T.S., Hanady M.A.A. "Effects of cellulose fibers on the properties of asphalt mixtures. Materials today: Proceeding, In press, Corrected Proof, Februari 2021.

[9] Badan Standarisasi Nasional. "Tata cara pelaksanaan lapis aspal beton (LASTON) untuk jalan raya”, Revisi SNI 03-1737-1989.

[10] Sukirman, S. "Beton Aspal Campuran Panas”. Grafika Yuana Marga, Bandung, 2003.

[11] Badan Standarisasi Nasional. "The test method for fine aggregate and coarse aggregate sieve analysis". Pustran-Balitbang Pekerjaan Umum, SNI 03-1968-1990. 
Journal of Engineering and Applied Technology

Vol. 1, No. 2, August 2020, pp. 97-109

[12] Badan Standarisasi Nasional. "Aggregate Wear Testing Methods with the Los Angeles Abrasion Machine". Pustran Balitbang Pekerjaan Umum”. SNI 03-2417-1991.

[13] Badan Standarisasi Nasional. "Asphalt penetration test method". SNI 2432-2011.

[14] Badan Standarisasi Nasional. "Flashpoint and burn point testing method with Cleveland open cup". RSNI 06-2433-1991.

[15] Badan Standarisasi Nasional. "Asphalt specific gravity testing method". Pustrang Balitbang Pekerjaan Umum. SNI 06-2441-1991.

[16] Badan Standarisasi Nasional. "Asphalt mixture testing method using Marshall apparatus". SNI 06-2489-1991.

[17] Badan Standarisasi Nasional. "Testing Methods of Hot Asphalt Mixtures with Marshall apparatus". RSNI M-01-2003.

[18] Giovanni, P., Sara, Filippi., Filippo, M., George, S. "A review of the fundamentals of polymermodified asphalts: Asphalt/polymer interactions and principles of compatibility", Advances in Colloid and Interface Science. vol. 224, pp. 72-112, October 2015.

[19] Jiqing, Z., Björn B, Niki, K. "Polymer modification of bitumen: Advances and challenges", European Polymer Journal, vol. 54, pp. 18-38, May 2014. 